\title{
PERAN GURU DALAM MENANAMKAN NILAI-NILAI KEDISIPLINAN DI PAUD AL-ANISA KELOMPOK B BENTIRING OIS KOTA BENGKULU
}

\author{
Rika Partikasarii ${ }^{1, a)}$, Sysva Nurwita ${ }^{1)}$, Neneng Uliya ${ }^{2)}$ \\ ${ }^{1)}$ Program studi Pendidikan Guru PAUD Universitas Dehasen Bengkulu \\ a)Corresponding Author: rkpar85@gmail.com
}

\begin{abstract}
This study aims to determine the role of teachers in instilling disciplinary values in Paud Al-Anisa group $B$ bentiring, Bengkulu City. This research is a qualitative descriptive study. Descriptive research is research directed to provide symptoms, facts or events systematically and accurately, regarding the characteristics of populations or specific regions. Data collection used is observation, documentation, interviews. Teachers as educators who play a role in learning provide concepts of knowledge and even the formation of attitudes and behavior. The role of the teacher in instilling the values of early childhood discipline is for the child to apply the concept of discipline that will be instilled by the teacher. The character of discipline that is expected to be possessed by children can be achieved through daily learning activities. The implementation of this research was carried out for a month, namely from March to April 2019. The research subjects were teachers in Al-Anisa PAUD Bengkulu City amounting to 4 teachers. By using the data analysis, the researchers present the results of the study that the teacher's role in instilling disciplinary values is very good. Based on the results of the previous analysis and discussion, the researcher can conclude that the teacher's role in instilling the values of discipline through 10 indicators will be instilled using. Through various methods, it is expected to be an intermediary in instilling the values of early childhood discipline so that education provided to children can be optimized.
\end{abstract}

Keywords: Teacher Role, Disciplinary Values of Early Childhood

\begin{abstract}
Abstrak
Penelitian ini bertujuan untuk mengetahui peran guru dalam menanamkan nilai-nilai kedisiplinan di Paud Al-Anisa kelompok B bentiring Kota Bengkulu. Penelitian ini merupakan penelitian deskriptif kualitatif. Penelitian deskriptip adalah penelitian yang diarahkan untuk memberikan gejala-gejala, fakta-fakta atau kejadian-kejadian secara sistematis dan akurat, mengenai sifat-sifat populasi atau daerah tertentu. Pengumpulan data yang digunakan adalah observasi, dokumentasi, wawancara. Guru sebagai pendidik yang berperan dalam hal pembelajaran memberikan konsep ilmu bahkan pembentukan sikap dan perilaku. Peran guru dalam menanamkan nilai-nilai kedisiplinan anak usia dini adalah agar anak menerapkan konsep disiplin yang akan ditanamkan oleh guru. Karakter disiplin yang diharapkan untuk dimiliki oleh anak dapat dicapai melalui kegiatan pembelajaran sehari-hari.Pelaksanaan penelitian ini dilakukan selama sebulan yaitu dari bulan Maret sampai bulan April 2019. Subjek penelitian adalah guru di PAUD Al-Anisa Kota Bengkulu berjumlah 4 orang guru. Dengan menggunakan analisis data tersebut maka peneliti mengemukakan hasil penelitian bahwa peran guru dalam menanamkan nilai-nilai kedisiplinan bernilai sangat baik. Bedasarkan hasil analisis dan pembahasan sebelumnya, maka peneliti dapat menyimpulkan bahwa peran guru dalam menanamkan nilai-nilai kedisiplinan melalui 10 indikator yang akan di tanamkan dengan menggunakan. Melalui berbagai metode diharapkan menjadi perantara dalam menanamkan nilai-nilai kedisiplinan anak usia dini sehingga pendidikan yang diberikan kepada anak bisa lebih optimal.
\end{abstract}

Kata Kunci : Peran Guru, Nilai-Nilai Disiplin Anak Usia Dini 


\section{Pendahuluan}

PendidikanAnakUsiaDini

padahakikatnyaialahpendidikan

(PAUD) yang

diselenggarakandengantujuanuntukmemfasilita sipertumbuhandanperkembangananaksecarame nyeluruhataumenekankanpadapengembangans eluruhaspekkepribadiananak usia dini. Pemberian stimulasi pada aspek yang dikembangkan, terutama karakter pada anakharus menggunakan metode yang tepat. Penyampaian cara yang benar akan memungkinkan terwujudnya pembiasaan sebagai perilaku terhadap karakter yang akan ditanamkan seperti karakter kedisiplinan (Mulyasa, 2015:34).

Menurut Undang-Undang Nomor 20 tahun 2003 tentang Sistem Pendidikan Nasional dikemukakan bahwa pendidikan merupakan usaha secara sadar dan terencana untuk mewujudkan suasana belajar dan proses pembelajaran agar peserta didik secara aktif mengembangkan potensi dirinya untuk memiliki kekuatan spritual keagamaan, pengendalian diri, kepribadian, kecerdasan, akhlak mulia, serta keterampilan yang diperlukan dirinya, masyarakat, bangsa dan negara.

Kedisiplinan pada anak-anak adalah memberikan pengertian akan mana yang baik dan yang buruk. Pendidikan disiplin perlu ditanamkan pada anak bahwa berbuat kesalahan memiliki sejumlah konsekuensi. Guru yang bijak dan profesional tidak pernah mempersoalkan latar belakang ras, suku, dan agama anak didiknya(Meity, 2015:10). Semua anak didiknya adalah pribadi manusia yang bermartabat mulia, anugerah sang pencipta. Semua murid dituntun untuk menuju manusia berkepribadian utuh, mencintai tuhan dan sesamanya sebagai insan berkarakter mandiri dan bertanggung jawab dalam memilihara dan mengelola hidupnya.

\section{Metode Penelitian}

Metode yang digunakan pada penelitian ini adalah Deskriptif kualitatif. Penelitian kualitatif adalah metode penelitian yang berlandaskan pada filsafat postpositivisme, digunakan untuk meneliti pada kondisi obyek yang alamiah, (sebagai lawannya adalah eksprimen) dimana peneliti adalah sebagai instrumen kunci, penelitian ini bermaksud untuk memahami situasi sosial secara mendalam seperti menanamkan nilai-nilai karakter khususnya kedisiplinan (Borg and Gall, 2008:78).

Prosedur penelitian yang digunakan adalah deskriptif. Penelitian deskriptip adalah penelitian yang diarahkan untuk memberikan gejala-gejala, fakta-fakta atau kejadiankejadian secara sistematis dan akurat, mengenai sifat-sifat populasi atau daerah tertentu. Dalam penelitian deskriptif cenderung tidak perlu mencari atau menerangkan saling hubungan dan menguji hipotesis (Yatim Riyanto, 2010:65).

Penelitianinidilakukan di PaudAl-Anisa kelompok B BentiringKota Bengkulu. WaktupenelitiandimulaidariPukul07.30-11 .00 WIB. Pelaksanaan penelitian ini dilakukanselama sebulan yaitu daribulan Maret sampai bulanApril 2019.

Subjek penelitian adalah guru di PAUD Al-Anisa Kota Bengkulu berjumlah 4 orang guru dan anak murid kelompok B berjumalah 15 orang.

1. Pengumpulan data dengan observasi

Nasition (2013:90) menyatakan bahwa, observasi adalah dasar semua ilmu pengetahuan. Para ilmuan hanya dapat berkeja berdasarkan data, yaitu fakta mengenai dunia kenyataan yang diperoleh melalui observasi.Pengumpulan data observasi dilakukan sendiri oleh peneliti, observasi dilakukan meliputi proses pembelajaran di Paud. Hal-hal yang diobservasi antara lain kemampuan guru dalam menanamkan nilainilai kedisiplinan pada Anak Usia Dini .instrumen tersebut antara lain:

2. Check List

Check list atau bisa disebut daftar check merupakan alat observasi yang terdiri dari daftar item yang berisi nama-nama subyek dan faktor-faktor yang diselidiki. Ada atau tidaknya item itu ditandai dengan mengecek "Ya" atau "Tidak". Disiplin diartikan anak disiplin dalam menaati peraturan, bertanggung jawab diartikan anak bertanggung jawab dalam melakukan sesuatu, percaya diri diartikan anak percaya dan tidak malu sama teman-temannya, sedangkan mandiri diartikan anak sudah berani ditinggal orang tuanya saat di antar dari sekolah dan anak juga berani dalam segala hal contohnya sudah berani ke toilet sendiri tanpa ditemani. Berikut check list yang akan di observasi: 
3. Teknik pengumpulan data dengan dokumentasi

Dokumentasi merupakan catatan peristiwa yang suda berlalu. Dokomentasi bisa berbentuk tulisan, gambar, atau karya-karya monumental dari seseorang dokumen yang berbentuk tulisan misalnya catatan harian, sejarah kehidupan (life histories), kriteria, biografi, peraturan, kebijakan. Dokumen yang dikumpulkan berbentuk gambar, misalnya foto, video, catatan dan lain-lain. Dokumentasi digunakan untuk memperoleh data sekolah dan nama anak-anak di Kelompok B Paud serta foto rekaman proses tindakan penelitian yang akan dilakukan.

4. Teknik pengumpulan data dengan wawancara

Wawancara merupakan suatu teknik pengumpulan data dengan jalan mengadakan komunikasi dengan sumber data. Komunikasi tersebut dilakukan dengan dialog (Tanya jawab) secara lisan, baik langsung maupun tidak langsung (I.Djumhur, 2004:65). Wawancara adalah salah satu untuk dapat mendapatkan data anak atau guru dengan mengadakan hubungan secara langsung. Berikut wawancara yang akan ditanyakan:

Tabel 1.Wawancara

\begin{tabular}{|c|l|}
\hline No. & \multicolumn{1}{|c|}{ Uraian } \\
\hline 1 & Bagaimana cara menumbuhkan rasa \\
2 & kemandirian pada anak? \\
3. & Bagaimana cara menanamkan nilai- \\
4. & nilai kedisiplinan pada anak? \\
5. & Bagaimana cara melatih anak \\
6. & menumbuhkan rasa kepatuhan pada \\
7. & anak? anaimana cara melatih anak \\
8. & bertanggung jawab? \\
& Bagaimana cara menumbukan rasa \\
& kepatuhan pada anak? \\
& Bagaimana cara menumbuhkan rasa \\
& keteraturan pada anak? \\
& Apakah ibu sudah menanamkan \\
& nilai-nilai kedisiplinan pada anak? \\
& Apakah anak sudah mulai disiplin \\
& saat ibu sudah menanamkan nila- \\
nilai kedisiplinan pada anak?
\end{tabular}

Sampel Sumber Data

Pada penelitian ini sumber data yang dilakukan adalah tindakan pembelajaran yang akan dilakukan dan dikembangkan selama proses penelitian dilakukan. Data yang digunakan adalah deskriptif kualitatif dengan analisis interaktif yang reduksi data, penyajian dan penarikan kesimpulan dilakukan dengan pengumpulan data.

Teknik Pengumpulan Data

Pada penelitian teknik pengumpulan data yang dilakukan adalah observasi, kegiatan ini dilakukan oleh peneliti dengan pengamatan bedasarkan aspek-aspek yang diidentifikasi, waktu pelaksanaan, metode dan tindakan yang dilakukan peneliti, tingkah laku anak serta kelemahan dan kelebihan anak yang ditemukan. Adapun aspek yang di amati adalah karakter anak saat melakukan kedisiplinan.

\section{Teknik Analisis Data}

Penelitian ini merupakan penelitian deskriptif kualitatif, dalam analisis data dilakukan dengan cara "mendeskripsikan". Adapun untuk mengelola data-data kualitatif ini dengan mengadakan observasi , reduksi data, penyajian dan penarikan kesimpulan atau verifikasi.

1. Observasi dilakukan terhadap subjek penelitian untuk memahami dalam proses pembelajaran di Paud.

2. Reduksi data yang dilakukan untuk mengetahui hal yang perlu di analisis, sehingga akan mudah dipahami, dimengerti dan dapat disajikan dengan baik.

3. Pada tahap penyajian data peneliti berusaha untuk menarik kesimpulan terhadap data-data yang diporoleh dari lokasi penelitian selama penelitian berlangsung.

\section{Hasil Penelitian}

Pada tahun 2012 Paud Al-Anisa mulai dikenal oleh masyarakat sekitar dari mulut ke mulut, sehingga ada beberapa wali murid menitipkan anaknya ke Paud Al-Anisa dan pada akhirnya Paud Al-Anisa memiliki 25 murid. Dari situlah kemudian kepala sekolah Paud Alanisa mulai mengajukan proposal ke Diknas Provinsi Bengkulu dan sejak saat itulah Paud Al-Anisa mendapatkan bantuan berupa APE luar dan dalam seperti perosotan, puzzle, buku bacaan, boneka tangan, pohon angka dan lainlain.

Akhirnya tahun-tahun berikutnya dan sampai saat ini Paud Al-Anisa mulai berkembang baik itu dari murid-muridnya, fasilitasnya, ruangan belajarnya dan lain sebagainya. Saat ini Paud Al-Anisa memiliki 30 
orang murid, 20 orang murid di kelompok Taman Kanak-Kanak (TK), 10 orang murid di Kelompok Bermain (KOBER), dan masingmasing kelas terdapat 1 orang guru kelas.

1. Pada tabel diatas dapat di deskripsikan yaitu:

a. Disiplin

Disiplin sangatlah penting bagi anak usia dini, bedasarkan hasil observasi di Paud Al-Anisa guru mengajarkan disiplin dari awal masuk sekolah sampai pulang dari sekolah. Di Paud Al-Anisa mengajarkan anak untuk disiplin waktu datang sekolah disiplin dalam belajar dan disiplin dalam melakukan suatu yang dikerjakannya.

b. Bertanggung Jawab

Anak usia dini harus diajarkan mengenai sikap bertanggung jawab. Sikap ini sangat penting mengingat bahwa sikap ini akan dibawa hingga kelak anak menjadi dewasa. Bedasarkan hasil observasi guru mengajarkan sikap bertanggung jawab agar anak bisa menyelesaikan tugasnya dengan baik dan berusaha sendiri tanpa bantuan orang lain.

c. Percaya diri

Percaya diri merupakan salah satu aspek kepribadian yang sangat penting dalam kehidupan. Rasa percaya diri anak perlu ditanamkan sejak dini. Bedasarkan hasil observasi, guru membangun rasa percaya diri pada anak dimulai dari kesadaran, bahwa rasa percaya diri berasal dari dalam diri anak masing-masing. Cara yang paling mendasar bagi guru paud Al-Anisa adalah guru harus memberi kepercayaan pada anak, supaya anak yakin akan kemampuan diri anak itu sendiri.

d. Mandiri

Mandiri adalah sikap dan perilaku anak yang mencerminkan perbuatan yang cenderung individual, tanpa bantuan dan pertolongan dari orang lain. Berdasarkan hasil observasi, anak- anak diajarkan banyak hal dengan melibatkan anak-anak untuk melakukan sesuatu sesuai dengan apa yang dipelajari. Sehingga tugas guru hanyalah mengamati dan membimbing. Guru membiarkan mereka mengerjakan tugas dengan sendiri agar anak bisa menjadi mandiri dan terhindar dari sifat ketergantungan pada

Pada tabel sebelumnya membahas tentang pengelolaan dan analisis data yang diperoleh melalui penelitian yang dilakukan. Dimana data tersebut peneliti dapatkan melalui wawancara dan observasi sebagai metode pokok dalam pengumpulan data, untuk mengambil suatu keputusan yaang objektif dan dapat berfungsi sebagai fakta. Penelitian ini berawal dari observasi yang penulis lakukan untuk mengamati peran guru dalam menanamkan nilai-nilai kedisiplinan anak usia dini di Paud Al-Anisa kelompok B Bentiring kota Bengkulu tahun pelajaran 2019-2020.

Dalam menganalisis data, penulis menggunakan metode deskriptif, yang berarti metode ini mengambil kesimpulan hasil observasi kegiatan belajar mengajar dan interview pada guru di Paud Al-Anisa. Setelah data terkumpul, maka dilanjutkan dengan data induktif, yaitu menganalisis data yang bertitik tolak dan fakta-fakta yang bersifat khusus kemudian disimpulkan secara umum, adapun penulis analisis adalah peran guru dalam menanamkan nilai-nilai kedisiplinan anak usia dini di paud al-anisa kelompok B Bentiring kota Bengkulu.

Bedasarkan hasil observasi penulis dilapangan, bahasannya adalah langkahlangkah yang telah dilaksanakan oleh guru Paud Al-Anisa Bentiring kota Bengkulu dalam menanamkan nilai-nilai kedisiplinan anak usia dini di Paud Al-Anisa kelompok B Bentiring kota Bengkulu adalah sebagai berikut:

1. Hadir tepat waktu

2. Berpakaian rapi

3. Merapikan sepatu ke rak sepatu

4. Berbaris rapi sebelum masuk kelas

5. Berdoa sebelum belajar

6. Proses pembelajaran

7. Mencuci tangan sebelum dan sesudah makan

8. Berdoa sebelum dan sesudah makan

9. Recalling

10. Bernyanyi

Bedasarkan hasil observasi penelitian di lapangan, dapat diuraikan sebagai bahwa dalam upaya peran guru dalam menanamkan nilainilai kedisiplinan anak usia dini di Paud AlAnisa Kelompok B Bentiring Kota Bengkulu sebagai berikut:

1. Hadir tepat waktu

Bedasarkan hasil observasi terlebih dahulu guru harus mampu mengciptakan hubungan baik dan akrab dengan anak sehingga anak merasa nyaman. Sebelum anak hadir tepat waktu disekolah terlebih dahulu guru harus datang lebih awal dari anak. Anak dibiasakan mengucapkan 
salam, saat datang anak harus bersalaman kepada guru dan orang tua/wali yang mengantarnya kesekolah.

2. Berpakaian rapi

Berpakaian rapi juga termasuk salah satu hal yang penting dalam kedisiplinan dan termasuk indikator kedisiplinan. Di paud al-anisa anak diajarkan berpakaian rapi saat datang sekolah. Pakaian seragam paud Al-Anisa yaitu:

a. Hari senin dan selasa seragam polisi

b. Hari rabu dan kamis seragam batik

c. Hari jumat seragam olahraga

Dalam kedisiplinan anak terbiasa berpakaian rapi disekolah guru juga memasukan dalam rencana kegiatan harian (RKH) yaitu dalam tema kebutuhanku sub tema pakaian. Guru memasukan ke dalam materi pembiasaan berpakaian rapi saat disekolah.

3. Merapikan sepatu ke rak sepatu

Merapikan sepatu ke rak sepatu merupakan sikap disiplin yang harus ditanamkan kepada anak, ketika anak sudah terbiasa merapikan sepatu ke rak sepatu dimanapun ia berada, ia akan menyukai kerapihan dan keindahan dimanapun ia berada. Bedasarkan hasil observasi, terlihat pada kegiatan spontan pembiasaan disiplin melalui ke jalan khusus dalam pembentukan prilaku anak yaitu dengan membiasakan anak untuk merapikan sepatu pada raknya ketika masuk sekolah ataupun ketika selepas bermain di halaman sekolah. Kegiatan pembiasaan rutin ini diharapakan anak dapat melakukan pembiasaan disiplin rapi dan bersih dimanapun ketika anak itu berada nantinya sehingga kegiatan disiplin yang diterpakan di Paud Al-Anisa secara terus menerus akan memberikan suatu pola atau suatu karakter anak yang disiplin dan menyukai keindahan dan kerapihan.

4. Berbaris rapi sebelum masuk kelas Membiasakan berbaris rapi merupakan hal yang sangat penting bagi anak karana dengan membiasakan anak untuk terbiasa mengantri dengan rapi maka akan memberikan pengaruh yang amat baik ketika anak tumbuh menjadi pribadi yang dewasa. Berdasarkan hasil observasi di paud Al-Anisa anak diajarkan untuk berbaris rapi sebelum masuk kelas anak juga harus tertib dalam mengantri tidak ada yang rebutan, barisan yang paling rapi akan disuruh masuk ke kelas duluan.

5. Berdoa sebelum belajar dan sesudah belajar

Berdoa adalah memohon atau meminta sesuatu yang besifat baik kepada Allah SWT. Berdasarkan hasil observasi anak dibiasakan berdoa sebelum belajar dan sesudah belajar agar kebiasaan ini akan dilakukan anak untuk memulai pelajaran.

6. Proses pembelajaran

Berdasarkan hasil observasi, proses pembelajaran dilakukan dengan tertib. Anak disuruh duduk rapi ke tempat duduknya masing-masing. Saat mau mulai proses pembelajaran guru mengingatkan kepada anak tidak boleh ribut dan saat selesai pembelajaran anak harus merapikan buku, pensil dll harus dikembalikan ke tempat semula.

7. Mencuci tangan sebelum dan sesudah makan

Berdasarkan hasil observasi, guru membiasakan anak untuk mencuci tangan sebelum dan sesudah makan sebelum mencuci tangan anak harus berbaris rapi saat antri mau cuci tangan dan tidak ada yang rebutan. Anak juga membiasakan makan menggunakan tangan kanan bukan tangan kiri.

8. Berdoa sebelum dan sesudah makan

Berdoa adalah memohon atau meminta sesuatu yang besifat baik kepada Allah SWT. Bedasarkan hasil observasi Anak dibiasakan berdoa sebelum dan sesudah makan. Saat makan anak tidak boleh ngobrol ataupun bermain sama temanya, anak harus menghabiskan makanan yang dibawanya ke sekolah, sesudah makan anak harus membersikan dan merapikan tempat makannya.

9. Recalling

Berdasarkan hasil observasi, guru menanyakan kepada anak bagaimana perasaan anak saat melakukan kegiatan sekolah pada hari itu dan apa saja yang telah dipelajari saat itu. Anak menjawab harus dengan tertib dengan menunjukan tangannya ke atas saat mau menjawab pertanyaan gurunya.

10. Bernyanyi

Berdasarkan hasil observasi, sebelum pulang anak melakukan kegiatan bernyanyi bersama-sama 


\section{Pembahasan}

Berkaitan dengan proses analisis data dan berdasarkan data diatas, maka pada bagian ini peneliti akan menguraikan hasil observasi dan wawancara dapat di jelaskan bahwa guru mengunakan pembiasaan dalam menanamkan nilai-nilai kedisiplinan anak dan juga menggunakan berbagai indikator capaian perkembangan disiplin anak bertujuan untuk mempermudah guru dalam mencapai tujuan yang akan di capai.

Peran guru dalam menanamkan nilai-nilai kedisiplinan berdasarkan hasil observasi dan wawancara yang telah dilakukan dapat ketahui bahwa guru telah menanamkan kedisiplinan pada anak. Guru telah menanamkan kedisiplinan disekolah seperti hadir tepat waktu, sebelum anak hadir guru harus mencontohkan guru harus lebih awal datang kesekolah sebelum anak. Kegiatan selanjutnya meletakan sepatu ke rak sepatu, guru juga meletakan sepatu ke rak sepatu sehingga anak tau bahwa guru juga ikut disiplin .

Sebelum kegiatan berbaris rapi anak sudah berbaris saat guru membunyikan bel sekolah, tapi beberapa orang yang tidak berbaris rapi seperti Bram, Bram tidak mau berbaris karena Bram emang tidak mau bebaris bedasarkan hasil observasi yang saya lihat Bramdan Maher tidak mau berbaris kerena Bram sebelum itu Bram berkelahi sama temanya gara-gara rebut mainan, cara guru mendisiplinkanya yaitu dengan cara siapa yang tidak berbaris rapi nanti tidak boleh masuk. Lalu ada juga yang tidak berbaris rapi misalnya Wawa, Wawa mau berbaris rapi mau bebarisjikatidakdengan sama teman akrabnya sehingga guru mendisiplinkanya dengan cara Wawa berbaris di samping temannya itu.

Cara

mendisiplinkananakdalamberpakaianseperti

Bram denganmemujinya, kata-kata pujianituseperti,kalau berpakaian rapi Bram nanti kelihatan ganteng, dengan dipuji anak tersebutmerasasenang. Padakeesokanharinya Bram selaluberpakaianrapi.

Kegiatan berdoa semua melakukan nya dengan baik seperti Arinda, Aurel, Bima, Chelsy, dst. Kerena berdoa selau diajarkan sebelum memulai pelajaran dan saat memulai kegiatan makan.

Kegiatan bernyanyi anak berkembang sangat baik kerena semuanya sangat semangat kalau bernyanyi apalagi anak-anak bernyanyi pakai mic dan bergantian saat bernyanyi kerena anak suka bernyanyi pakai mic

Dalam kegiatan recalling berkembang sangat baik kerena recalling pelajaran yang telah dilakukan dan di ulang lagi apa yang telah pelajari, anak- anak sangat disiplin saat recalling, guru menunjuk satu persatu ke anak dan diulangi apa yang kita pelajari tadi.

Kegiatan mencuci tangan perkembangan anak sangat baik kerena sebelum makan harus mencuci tangan, anak harus mengantri sebelum cuci tangan, berdasarkan hasil observasi yang saya lihat anak saat mengantri mencuci tangan tidak ada saling dorong-dorong karena hal itu guru telah menanamkan nilai-nilai kedisiplinan disekolah.

Peran guru dalam menanamkan nilai-nilai kedisiplinan anak sudah berhasil tapi ada beberapa anak dalam indikator belum berhasil, indikator dalam proses pembelajaran, bebaris rapi dan berpakaian rapi. Dalam proses pembelajaran ada seorang anak yang belum disiplin seperti Bram, Wawa, dan Maher. Dalam kegiatan proses pembelajaran Bram selalu mencontoh punya temanya dan Bram tidak mandiri saat melakukan tugas apa yang diberi oleh gurunya dan Bram selalu mengeluh saat belajar dalam hal tersebut cara guru untuk mendisiplinkanya yaitu dengan cara siapa yang cepat selesai tugasnya nanti paling duluan bermain, begitupun denganMaher.

Peran guru dalam menanamkan nilai-nilai kedisiplinan di Paud Al-Anisa sudah ditanamkan sehingga yang perkembangan anak sangat baik dan sudah disiplin seperti Arinda, Zidan, Irvan dst. Karena guru sudah menanamkan nilai-nilai kedisiplinan dengan membuat daftar tata tertib, memberikan reward yang positif, memberikan bimbingan dan arahan dalam mengambil keputusan, guru juga memberikan contoh yang baik kepada anak, memberikan kata-kata yang jelas untuk aturan/perilaku kepada anak, tegas, konsisten dengan peraturan yang sudah dibuat, lakukan pembinaan, itu adalah hasil observasi wawancara yang telah dilakukan.

Guru juga mengajarkan rasa kepatuhan kepada anak dengan cara perilaku dan hormati anak seperti anda menghormati orang dewasa,berikan contoh yang baik, berikan pujian. Guru selalu menumbuhkan rasa keteraturan pada anak dengan membimbing anak untuk selalu mengikuti peraturan yang sudah telah dibuat sebelumnya. 
Guru juga harus mencontohkan kedisiplinan kepada anak sehingga anak juga akan mencontoh perilaku guru tersebut, guru tidak boleh kasar ataumelukaidalam mendisiplinkan. Guru harus lebih tegas dan sabar dalam mendisiplinkan anak dan ramah kepada anak sehingga anak akan sopan kepada guru jika guru menghormatinya.

Dalam peran guru dalam menanamkan nilai-nilai kedisiplinan anak harus sabar dan harus berulang-ulang kali dilakukan tidak cukup sekali dalam mendisiplinkanya karena dalam berulang anak akan mengingat apa yang harus dilakukan agar mudah diterapkan ke jenjang berikutnya.

\section{Kesimpulan}

Bedasarkan hasil analisis data dan pembahasan sebelumnya, maka peneliti dapat disimpulkan mengenai peran guru paud dalam menanamkan nilai-nilai kedisiplinan anak usia dini di Paud Al-Anisa kelompok B Bentiring Kota Bengkulu melalui observasi, dokumentasi dan wawancara. Peneliti juga mengamati observasi pembiasaan dan keteledanan yang diterapkan kepada anak dan mudah dimengerti dan mengikuti kedisiplinan yang telah guru tanamkan disekolah tampa adanya unsur dan paksaan, anak melakukan kedisiplinan tersebut dengan hati senang dan gembira.

Dalam menanamkan nilai-nilai kedisiplinan terdapat 10 indikator sebagai berikut: 1). Hadir tepat waktu, 2). Berpakaian rapi, 3). Berbaris rapi, 4). Merapikan sepatu ke rak sepatu, 5). Berdoa sebelum dan sesudah belajar, 6). Berdoa sebelum dan sesudah makan, 7). Bernyanyi, 8). Recaling, 9). Mencuci tangan sebelum dan sesudah makan, dan 10). Proses pembelajaran.

Melalui kegiatan keseharian disekolah dapat terlihat setelah dilakukannya peran guru dalam menanamkan nilai-nilai kedisiplinan di Paud Al-Anisa Kelompok B Bentiring Kota Bengkulu menggunakan upaya yang tepat , anak mulai menunjukan kedisiplinan sangat baik yang diterapkan di Paud Al-Anisa.

\section{Daftar Pustaka}

Aulina, Choirun Nisak, (2013). Penanaman Disiplin Anak Usia Dini. Sidoarjo: Universitas Muhammadiyah Sidoarjo.
Arikunto, S. (2005). Manajemen Pengajaran Secara Manusiawi, Jakata: PT. Rineka Cipta.

Cahyaningrum, Eka. (2017). Pengembangan Nilai-Nilai Karakter Anak Usia Dini Melalu Pembiasaan dan Keteladanan, Yogjakarta: Universitas Negeri Yogyakarta

Departemen Pendidikan Nasional. (2003). Undang-Undang Sistem Pendidikan Nasional (UU RI No. 20 tahun 2003) dan Peraturan Pelaksanaanya. Jakarta: Departemen Pendidikan Nasional.

Depdiknas, (2005). Pembinaan Profesionalisme Tenaga Pengaja (Pengembangan Profesionalisme Guru). Jakarta: Direktorat Jenderal Pendidikan Dasar dan Menengah Direktorat Pendidikan Lanjutan Pertama, Depdiknas.

Dolet, Unaradjan. (2003). Manajemen Disiplin. Jakarta:PT. Gramedia Widiasarana.

Evi. 18/trik/cara mendisiplinkan anak-ibu dan balita. ( 12 desember 2012). Diakses Januari. Https://www.ibudanbalita.com

Hulock, Elizabeth. (2002). Perkembangan Anak. Erlangga:Jakarta.

Hurlock, Elizabeth B. (2002). Perkembangan Anak. Jakarta: Erlangga.

Idris, H Meity, (2015). Strategi Pembelajaran Menyenangkan. Jakarta Timur: PT Luxima Metro Media.

I.Djumhur, (2016). Metedelogi Peneletian. Jakarta: PT. Refika Aditama.

Kemendikbud. (2017). Pengasuhan Positif. Direktorat Pembinaan Pendidikan Keluarga. Jakarta: Kemdikbud.

Konstelnik, Marjorie J.et all. (2007). Developmentally Appropriate Curriculum Ohio: Pearson.

Mulyasa. (2012). Manajemen PAUD. Bandung: Remaja Rosdakarya.

Mulyasa. (2005). Manajemen Paud. Bandung: Remaja Rosdakarya.

Myrnawati, Edy. (2018). Pengaruh Keterlibatan Orang Tua dan Pola asuh Terhadap Disiplin Anak. Jakarta: Universitas Negeri Jakarta

Riyanto Yatim, (2010), Metodologi Penelitian Pendidikan, Surabaya:Anggota KAPI No. 035/JTI

Saondi, Ondi. (2012). Etika Profesi Keguruan. Bandung: PT Refika Aditama. 
Shapiro, E, L. (2001). Mengajarkan Emotional Intelegence Pada Anak. Jakarta:Gramedia Pustaka Utama.

SheKnows. Cara Mendisiplinkan Anak Bedasarkan Umur. (17 juli 2010). Diakses Januari 2019.

Https://M.detik.com/heath/ibuanak/detailartikel.

Shochib, M. (2017). Pola Asuh Orangtua dalam Membantu Anak Mengembangkan Disiplin Diri. Jakarta: PT Rineka Cipta.

Slameto. (2002). Belajar dan Faktor-Faktor yang Mempengaruhinya. Edisi Revisi. Jakarta: PT Rineka Cipta.

Soetjiningsih. (2009). Tumbuh Kembang Anak, Jakarta:EGC.

Sutopo HB, (2003). Metode Penelitian Kualitatif, Metode penelitian ilmu Sosial dan Budaya, Surakata:UNS.

Prawoto. (2009). Profesi Guru, Jakarta: PT. Rineka Cipta 